\title{
Model Posdaya Dalam Penuntasan Wajib Belajar Pendidikan Dasar 9 Tahun
}

\author{
Oos M. Anwas \\ Pustekkom Kemendiknas, Email: anwasipb@yahoo.co.id
}

\begin{abstract}
Abstrak:. Tulisan ini bertujuan mengkaji solusi dalam mengatasi masalah tersebut melalui model Pos Pemberdayaan Keluarga (Posdaya). Teori-teori yang digunakan mengacu pada teori perubahan sosial dan teori pemberdayaan masyarakat. Dengan kompleksnya masalah yang dihadapi kelompok masyarakat hard rock tersebut, penuntasan wajar 9 tahun perlu dilakukan melalui upaya pemberdayaan keluarga dalam wahana Posdaya. Posdaya merupakan forum silaturahmi, komunikasi, advokasi dan wadah kegiatan penguatan delapan fungsi-fungsi keluarga secara terpadu. Pengembangan Posdaya tidak harus membuat lembaga baru dalam masyarakat, tetapi dapat mengoptimalkan yang ada melalui aktivitas pemberdayaan. Posdaya menjadi wahana diskusi dalam memecahkan permasalahan sehari-hari, khususnya kendalakendala penuntasan wajar 9 tahun secara bersama antara anak, orang tua, dan masyarakat sesuai dengan kebutuhan dan potensi/peran masing-masing. Posdaya juga mampu membangun kembali kearifan lokal dan modal sosial. Pada akhirnya Posdaya tidak hanya memecahkan masalah pendidikan, akan tetapi juga masalah kemiskinan dan masalah sosial lainnya. Oleh karena itu penuntasan wajar 9 tahun perlu kerja sama lintas departemen di bawah koordinasi Menkokesra, terutama sektor pendidikan, kesehatan, dan kewirausahaan, bersama pemerintah daerah dan masyarakat.
\end{abstract}

Kata Kunci: wajib belajar pendidikan dasar 9 tahun, Posdaya, pemberdayaan keluarga, forum komunikasi, modal sosial.

Abstract: This paper aims to analyze solutions for the problems using Family and The Community Empowering (Posdaya). Theories used within this model refers to social change and community empowerment theories. Since the complexity of problems face by those hard rock society, the accomplishment of nine-year compulsory learning must be done by means of family empowerment within Posdaya. Posdaya is a forum for communications, 'silaturahmi', advocacy and education, and simultaneously the institution for activities to strengthen family functions in an integrated manner. Instead of establishing a new institution, the development of Posdaya can be done by optimizing the existing one by empowering activities. Posdaya become a place for discussing daily matters, especially the obstacles in accomplishing the nine-year compulsory learning, among children, parents and community that are fit with their own needs and potential/roles. Posdaya is also capable in re-developing local wisdom and social capital. At the end Posdaya is not only to solve educational problems but also to solve poverty and other social problems. For those reasons the accomplishment of nine-year compulsory learning requests cooperation across departments within coordination of welfare ministry in collaboration with local government and society.

Key words: nine-year compulsory education, Posdaya, family empowerment, communication forum, social capital.

\section{Pendahuluan}

Pembangunan secara umum identik dengan proses perubahan terencana, ke arah perbaikan kondisi yang lebih baik. Kata kunci dari konsep pembangunan adalah perubahan, pertumbuhan, pemenuhan kebutuhan, peningkatan martabat dan harga diri (Susanto, 2007). Pembangunan sektor pendidikan merupakan pembangunan yang berpusat pada manusia. Pembangunan pendidikan berarti perubahan untuk meningkatkan kualitas kehidupan manusia yang lebih baik dan bermartabat.

Pendidikan terutama pendidikan dasar merupakan hak setiap warga negara yang telah 
diakui sebagai kesepakatan dunia. Tahun 2000 Kepala Negara dari seluruh dunia atas studi dan kesimpulan PBB sepakat untuk mengarahkan dan mengukur pembangunan berbasis manusia dan masyarakat yang disebut Millennium Development Goals (MDGs). Ada delapan delapan sasaran MDGs yang akan ditindaklanjuti di setiap negara, salah satunya adalah pencapaian pendidikan dasar umum bagi semua warga negara.

Di Indonesia, penuntasan wajib belajar 9 tahun telah ditempuh melalui berbagai model, antara lain: SD/MI dan SMP/MTs reguler, SMP Satu Atap, SMP Terbuka, Kejar Paket A dan B, dan bentuk layanan lainnya. Sekolah regular ditujukan bagi siswa yang mampu mengikuti sekolah secara biasa masuk tiap hari pada jam sekolah. SMP Satu Atap dikembangkan pada daerah-daerah terpencil dengan menyatukan lokasi SD dengan SMP dengan memanfaatkan berbagai sumber, sarana dan prasarana pada SD tersebut. Model SMP Terbuka ditujukan bagi siswa yang tidak bisa datang tiap hari ke sekolah reguler karena berbagai hal, sehingga mereka bisa belajar mandiri melalui bahan belajar yang telah dirancang secara khusus. Kejar Paket A dan Paket B merupakan pendidikan nonformal penyetaraan setingkat SD dan SMP. Di samping itu, Pemerintah telah memberikan berbagai program dukungan lainnya misalnya: Program BOS/sekolah gratis, beasiswa, atau program kemudahan lainnya.

Upaya-upaya tersebut ditujukan dengan harapan semua anak usia sekolah pendidikan dasar (usia 7 s.d. 15 tahun) dapat mengikuti salah satu bentuk layanan pendidikan yang sesuai. Namun, kenyataannya bentuk layanan tersebut masih belum bisa menjaring semua anak-anak untuk mengikuti pendidikan dasar. Berdasarkan data Balitbang Depdiknas (2007), bahwa Angka Partisipasi Murni (APM) SD/MI dan setara tahun 2007/2008 sebesar 94,9\% dan Angka Partisipasi Kasar (APK) SMP/MTs dan setara mencapai $92,52 \%$. Ini berarti pencapaian penuntasan wajar 9 tahun hanya sekitar 7 persen lagi, namun ini adalah tantangan besar karena sisa pencapaian tersebut merupakan kelompok masyarakat yang tidak mampu ditangani dengan upaya yang telah dilakukan saat ini.

Jika kita cermati, semua alternatif penuntasan wajar 9 tahun tersebut masih berpusat kepada siswa. Padahal anak bisa sekolah sangat terkait dengan orang tua dan keluarganya. Jika anakanak mereka sekolahnya sudah gratis, diberikan buku-buku atau keperluan sekolah lainnya, satu dua hari mereka mau sekolah. Namun, ketika kembali ke rumahnya, orang tuanya menuntut untuk membantu bekerja, mencari nafkah dalam memenuhi kebutuhan primernya. Anak-anak yang belum mencapai wajar 9 tahun tersebut berasal dari kelompok masyarakat yang sulit atau hard rock. Kelompok masyarakat itu tersebar tidak hanya di daerah pedesaan atau daerah terpencil, melainkan juga berada di pinggiran kota dan juga perkotaan. Mereka umumnya berasal dari kelompok masyarakat yang masih miskin, terbelakang, dan cenderung termarjinalkan. Oleh karena itu, penuntasan wajar 9 tahun tidak bisa dilakukan hanya melalui sistem pendidikan saja, namun sistem lain yang terkait dengan pendidikan dan keluarga mereka sangat perlu dilibatkan. Ini berarti walaupun sasaran dari wajib belajar pendidikan dasar 9 tahun adalah anak usia SMP, tetapi orang tua dan masyarakat sekitarnya harus diberdayakan. Oleh karena itu, kata kuncinya adalah bagaimana memberdayakan mereka agar anak-anak bersemangat sekolah, serta orang tua dan masyarakatnya mampu dan mendukung anakanaknya untuk bersekolah.

Pos Pemberdayaan Keluarga (Posdaya) merupakan salah satu model pemberdayaan masyarakat yang dimulai dengan mengoptimalkan fungsi-fungsi keluarga dalam menyiapkan individu yang sehat dan mandiri, termasuk menyiapkan pendidikan bagi anak-anak mereka. Tulisan ini akan mengkaji model posdaya dalam menuntaskan wajib belajar 9 tahun, terutama terhadap kelompok masyarakat yang diasumsikan sulit (hard rock) tersebut.

\section{Kajian Literatur dan Pembahasan Hakikat Posdaya}

Konsep Posdaya, dikembangkan oleh Prof. Haryono Suyono mulai tahun 2006 sebagai pengembangan dari konsep Pos Pelayanan Terpadu (Posyandu). Penyegaran Posyandu tersebut diperlukan ketika di masyarakat muncul gejala terjadinya gizi buruk, timbulnya kembali polio serta penyakit menular lainnya. Banyak pihak mengkaitkan kejadian tersebut sebagai akibat 
makin menurunnya intensitas pembinaan dan kegiatan Posyandu, serta semaraknya eforia reformasi dan perebutan kekuasaan.

Seiring dengan kompleknya perkembangan dan perubahan zaman, masalah dan kebutuhan masyarakat dan keluarga Indonesia makin berkembang. Oleh karena itu, revitalisasi Posyandu dalam pemberdayaan keluarga tidak hanya pada aspek pelayanan Keluarga Berencana (KB) dan kesehatan, akan tetapi perlu dikembangkan lembaga pemberdayaan masyarakat, yang dibentuk oleh masyarakat, dan menjadi milik atau kebanggaan masyarakat. Lembaga ini harus bisa menampung berbagai masukan untuk mengembangkan keluarga agar mampu melaksanakan fungsi-fungsinya.

Posdaya dikembangkan untuk memberdayakan delapan fungsi keluarga secara terpadu. Kedelapan fungsi tersebut adalah fungsi agama atau Ketuhanan Yang Maha Esa, fungsi budaya, fungsi cinta kasih, fungsi perlindungan, fungsi reproduksi dan kesehatan, fungsi pendidikan, fungsi ekonomi atau wirausaha dan fungsi lingkungan. Posdaya adalah forum silaturahmi, komunikasi, advokasi dan wadah kegiatan penguatan fungsi-fungsi keluarga secara terpadu (Suyono dan Haryanto, 2009).

Kedelapan fungsi keluarga tersebut apabila dicermati dapat disarikan menjadi tiga sektor yaitu kesehatan, pendidikan, dan kewirausahaan. Ketiga sektor tersebut menurut Suyono (2003) merupakan pondasi dalam mewujudkan keluarga sejahtera. Ini bisa diasumsikan bahwa fisik dan psikis individu yang sehat, dihasilkan dari kemampuan dan perilaku yang baik dalam menjaga kesehatannya. Kemampuan ini diperoleh dari hasil pendidikan, baik pendidikan formal, informal, maupun nonformal. Individu yang berhasil mengikuti pendidikan ditunjang oleh ekonomi yang cukup. Ekonomi yang cukup ini juga diperoleh dari ilmu yang dimilikinya tentang berwirausaha sebagai hasil proses pendidikan yang ditunjang dengan jiwa raganya yang sehat. Sebaliknya, badan yang kurang sehat, akibat perilaku sehatnya juga kurang baik sebagai akibat dari kurang mampu memperoleh pendidikan, atau ketidakmampuan ekonomi keluarganya. Oleh karena itu, penuntasan wajib belajar 9 tahun pada kelompok masyarakat hard rock atau miskin perlu ditangani secara terpadu terutama dalam ketiga aspek tadi yang disesuaikan dengan kebutuhan dan potensi masyarakatnya.

Posdaya yang dikembangkan Yayasan Damandiri yang dimulai tahun 2006 hingga April 2009 ini telah mencapai 3.947 Posdaya yang tersebar di berbagai pelosok tanah air (Damandiri, 2009). Perkembangan Posdaya ini hasil kerja sama dengan pemerintah daerah kabupaten/ kota, antara lain: Serang, Bogor, Bekasi, Sragen, Purbalingga, Kulonprogo, Bantul, Malang, Jembrana, Banjarmasin, Pangkep, Bandarlampung, dan lain-lainnya; dengan lembaga perguruan tinggi (IPB Bogor, Unsoed Purwokerto, Undip Semarang, Unair Surabaya, UNS Surakarta, Unmer Malang, dan perguruan tinggi lainnya), LSM, dan pihak-pihak terkait lainnya. Ini menunjukkan bahwa penanganan masalah dalam masyarakat perlu didekati secara holistik dengan melibatkan berbagai unsur yang terkait dalam masyarakat.

\section{Pembentukan Posdaya dalam penuntasan wajib belajar 9 tahun}

Keberhasilan pemberdayaan masyarakat menurut Sumardjo (2008) kuncinya adalah melibatkan masyarakat seluas-luasnya, berpusat pada kebutuhan masyarakat, serta menggunakan pendekatan holistik. Kebutuhan, permasalahan, dan potensi setiap masyarakat sangat beragam. Oleh karena itu, pengembangan Posdaya dalam penuntasan wajib belajar 9 tahun sangat dimungkinkan dengan berbagai variasi pola dan bentuk Posdaya. Di sinilah tugas pemerintah dalam hal ini Depdiknas bersama pemerintah daerah dan masyarakat untuk merancang model Posdaya yang sesuai dengan sasaran. Pembentukan Posdaya ini dapat dimulai dengan pendataan siswa usia pendidikan dasar yang belum sekolah. Kelompok ini berada pada kelompok masyarakat miskin, daerah terpencil, suku terasing, termasuk juga masyarakat perkotaan dan juga pinggiran kota.

Pada kelompok masyarakat tersebut diperlukan ketokohan atau anggota masyarakat yang dituakan atau yang diikuti oleh masyarakat sekitarnya. Pendekatan kepada tokoh ini sangat penting, karena menurut Asngari (2007), dalam konteks perubahan sosial, masyarakat akan lebih 
percaya terhadap informasi/perubahan yang datang dari anggota masyarakatnya sendiri dibandingkan dengan orang di luar kelompoknya (orang asing). Proses penyadaran akan perlunya sebuah forum Posdaya kepada sang tokoh ini sangat menentukan. Di sisi lain penyadaran perlu juga diberikan kepada tokoh formal seperti kepala dusun atau kepala desa.

Proses penyadaran kepada tokoh dan masyarakat ini memang tidak mudah, apalagi Posdaya merupakan organisasi nonformal yang cenderung virtual, artinya tidak harus nyata memiliki kantor atau ruang sekretariat, yang penting aktivitasnya bisa dirasakan oleh anggotanya. Untuk meyakinkan masyarakat ini menurut Asngari (2007) diperlukan adanya bukti atau contoh keberhasilan yang telah melakukannya. Bahkan, menurut Slamet (2007) perlu dipahami betul akan manfaat yang akan diperoleh dari pembentukan organisasi baik langsung ataupun tidak bagi diri, keluarga, dan masyarakat sekitarnya. Selanjutnya pelatihan atau lokakarya bagi peserta calon pengurus juga perlu dilakukan. Di sini mereka belajar bagaimana membuat perencanaan yang disesuaikan dengan data kebutuhan dan potensi mereka.

Pembentukan Posdaya bukan dimaksudkan untuk mengganti pelayanan sosial ekonomi kepada masyarakat berupa pelayanan terpadu, tetapi semata-mata dimaksudkan untuk mengembangkan forum pemberdayaan terpadu yang dinamis, yaitu pemberdayaan pembangunan kepada pimpinan keluarga yang dipadukan satu dengan lainnya (Suyono dan Haryanto, 2009). Tujuannya adalah agar pimpinan keluarga mengetahui peran dan fungsinya. Akhirnya bisa melakukan pemberdayaan untuk anggotanya secara mandiri.

Pengembangan Posdaya yang didasarkan pada kebutuhan, potensi, dan juga budaya masyarakat setempat dalam implementasinya akan melahirkan banyak variasi. Pembentukan Posdaya juga tidak harus membentuk kelembagaan baru tetapi dapat mengembangkan kelembagaan yang telah ada di masyarakat, misalnya Posyandu, mesjid, gereja, sekolah, pesantren, kelompok ibu-ibu pengajian, kelompok tani, kelompok usaha, dan organisasi bentuk lainnya. Kelembagaan yang telah ada ini menjadi modal awal untuk selanjutnya dikembangkan. Model Posdaya yang dikembangkan Yayasan Damandiri di antaranya Posdaya berbasis mesjid, Posdaya berbasis SMA, Posdaya berbasis Masyarakat, bahkan di Kabupaten Jembrana Bali berkembang Posdaya berbasis Banjar (Damandiri, 2009).

Pengalaman Yayasan Damandiri dalam pengembangan Posdaya, di antaranya melibatkan perguruan tinggi melalui Lembaga Pengabdian Masyarakat, mahasiswa Kuliah Kerja Nyata, serta siswa-siswa SMA dengan bimbingan gurugurunya. Posdaya juga mendapat sambutan luar biasa dari pemerintah daerah kabupaten/kota seperti di Kabupaten Purbalingga dan Sragen Provinsi Jawa Tengah; Kabupaten Bantul, Sleman, dan Kulonprogo Provinsi DI Yogyakarta; Kota Bogor dan Kabupaten Bekasi Jawa Barat; Kota Serang Provinsi Banten; Kabupaten Jembrana Bali, Kabupaten Malang dan Lumajang Provinsi Jawa Timur, Kota Banjarmasin Provinsi Kalimaantan Selatan, Bandar Lampung Provinsi Lampung, dan daerah-lainnya (Damandiri, 2009). Kerja sama ini menunjukan bahwa pemberdayaan merupakan tugas bersama dan dilakukan melalui pendekatan holistik. Oleh karena itu, dalam pengembangan Posdaya untuk penuntasan wajib belajar 9 tahun, Depdiknas perlu menggandeng pihak terkait seperti: pemerintah daerah, departemen kesehatan, departemen atau kementerian lainnya yang berada di bawah koordinasi Menkokesra.

\section{Posdaya sebagai Forum Komunikasi}

Dalam kajian komunikasi, komunikasi yang paling efektif untuk mengubah perilaku adalah komunikasi interpersonal (Sendjaja, 1994). Di sisi lain menurut Asngari (2007) dalam kontek perubahan sosial, informasi perubahan akan lebih dipercaya dari anggota komunitasnya dibandingkan dengan orang lain. Posdaya merupakan wahana komunikasi interpersonal antaranggota atau komunitas mereka. Posdaya juga merupakan forum komunikasi dari, oleh, dan untuk masyarakat. Ini menunjukan komunikasi dalam wahana Posdaya ini akan mampu mengubah perilaku mereka, mengubah kebiasaan lama yang kurang baik menuju kehidupan yang lebih baik dan sejahtera. 
Untuk dapat membuat komunikasi yang bermanfaat bagi mereka, diperlukan subtansi atau materi komunikasi yang baik pula. Subtansi komunikasi yang baik dalam masyarakat adalah yang sesuai dengan kebutuhan, masalah, dan potensinya (Anwas, 2009). Artinya, sumber informasi ada dalam diri mereka sendiri. Informasi ini mulai dari yang sederhana, misalnya keperluan sehari-hari, tetangga yang sakit, orang yang perlu bantuan, anak tetangga yang tidak mau sekolah, orang tua yang kesulitan untuk menyekolahkan anak, anak yang tidak mau sekolah, dan informasi lainnya. Melalui forum ini mereka dibiasakan untuk terbuka, saling berbagi dan menerima, serta secara bersama memecahkan permasalahan yang dihadapinya. Mereka akan saling menegur, menasehati, memberikan pendapat, serta memecahkan masalah dengan cara atau kebiasaannya masing-masing. Apabila ada orang tua yang belum bisa menyekolahkan anaknya atau ada anak yang masih tidak mau sekolah dapat dibicarakan bersama.

Sumber informasi dari luar untuk perubahan tentu harus disesuaikan dengan kebutuhan dan tingkat pemahaman mereka. Informasi tentang pendidikan dasar misalnya sekolah gratis, bantuan BOS, SD/SMP reguler, SMP Terbuka, SMP satu atap, dan beberapa alternatif Iayanan pendidikan dasar lainnya sangat perlu dipahami mereka. Di sisi lain manfaat pendidikan formal baik untuk jangka pendek maupun jangka panjang, termasuk contoh keberhasilan atau testimoni keberhasilan anak-anak dari golongan seperti mereka, sangat penting bagi mereka.

Subtansi informasi ini tidak hanya terkait dengan pendidikan melainkan juga semua hal yang bisa meningkatkan kualitas kehidupan mereka. Informasi tentang cara-cara hidup sehat dan layanan kesehatan yang bisa mereka jangkau, informasi yang terkait dengan peningkatan ekonomi, peluang usaha, dan kesejahteraan juga penting.

Selanjutnya, saluran informasi apa yang tepat untuk mengubah perilaku mereka. Di dalam masyarakat terdapat sistem sosial. Sistem sosial dalam pengertian difusi inovasi dapat diartikan sebagai seperangkat unit sosial (individu, organisasi, keluarga atau bangsa) yang saling berhubungan dan bekerja sama dalam memecahkan persoalan bersama untuk mencapai tujuan tertentu. Sistem sosial ini dipengaruhi oleh struktur sosial, norma-norma sosial, dan opinion leader serta agen pembaharu (Rogers, 1995). Struktur sosial, norma-norma sosial, dan opinion leader serta agen pembaharu ini dapat menjadi saluran terhadap informasi. Menurut Kincaid dan Schramm (1987), penerusan arus informasi media yang terjadi tidak hanya dua tahap, atau tiga tahap, bahkan melewati beberapa tahap yang panjang. Khalayak tersusun atas jalinan perseorangan yang saling bertalian dengan pemimpinpemimpin yang pendapatnya mengandung pengaruh yang lebih besar untuk perubahan. Hal ini sejalan dengan teori two step flow dan konsep 'pemuka pendapat' dari Lazarsfeld (Sendjaja, 1994), serta teori difusi inovasi. Ini menujukan betapa penting peran tokoh masyarakat/adat sebagai saluran informasi dan penyadaran terhadap perubahan kehidupan mereka

Substansi informasi ini tidak terbatas pada aspek pendidikan melainkan juga semua hal yang terkait dengan kebutuhan dan masalah yang dihadapi mereka. Informasi ini sangat berguna untuk ditindaklanjuti dan dipecahkan bersama. Oleh karena itu, Depdiknas perlu melakukan kerja sama dengan intansi terkait terutama dengan pemerintah daerah setempat. Informasi yang dilakukan dengan subtansi yang sesuai dengan kebutuhan dan potensi mereka serta dilakukan secara kontinyu akan mampu memberikan pencerahan, sehingga mereka memiliki kesadaran yang utuh terhadap pendidikan dan peningkatan kualitas kehidupannya menuju keluarga sejahtera.

\section{Posdaya Membangun Modal Sosial}

Era informasi sebagai hasil kemajuan teknologi informasi dan komunikasi mengakibatkan perubahan besar dalam masyarakat. Produk teknologi informasi yang relatif murah dan terjangkau menjadikan semakin mudah mengakses informasi melampaui batas negara dan batas komunitas kultur yang sudah lama tertanam. Kondisi ini telah merambah kepada semua lapisan kehidupan manusia termasuk para petani di pedesaan. Namun pengaruh era informasi tidak selalu menimbulkan perubahan positif. Menurut Fukuyama (2000) era informasi telah menimbulkan kekacauan besar (great distruption) dalam tatanan nilai-nilai sosial. Kondisi sosial yang cenderung memburuk ditandai dengan 
adanya kejahatan dan kekacauan yang makin meningkat, kekerabatan makin menurun, kepercayaan kepada pemerintah menurun, tingkat keterlibatan dalam masyarakat menurun, serta menurunnya tatanan sosial lainnya. Masyarakat informasi juga telah melenggangkan globalisasi dan pasar bebas. Globalisasi melahirkan tingkat persaingan yang semakin ketat. Kondisi ini perlu disadari oleh manusia untuk melakukan berbagai upaya dalam membangun kembali tatanan sosial tersebut.

Salah satu tujuan Posdaya adalah menjawab kekhawatiran Fukuyama tentang kekacauan besar (great distruption) dalam tatanan sosial. Menurut Suyono dan Haryanto (2009) tujuan Posdaya adalah: 1) dihidupkannya dukungan sosial budaya atau social capital seperti hidup gotong royong dalam masyarakat untuk menolong keluarga lain membantu pemberdayaan secara terpadu atau bersama-sama memecahkan masalah kehidupan yang komplek, melalui wadah atau forum yang memberi kesempatan para keluarga untuk saling asah, asih, dan asuh, dalam memenuhi kebutuhan untuk membangun keluarga bahagia dan sejahtera; 2) terpeliharanya infrastruktur sosial kemasyarakatan yang terkecil dan solid, yaitu keluarga, yang dapat menjadi perekat atau kohesi sosial, sehingga tercipta suatu kehidupan yang rukun, damai dan memiliki dinamika yang tinggi; dan 3 ) terbentuknya lembaga sosial dengan keanggotaan dan partisipasi keluarga di desa atau kelurahan yang dinamis dan menjadi wadah atau wahana partisipasi sosial, di mana para keluarga dapat memberi dan menerima pembaharuan yang bisa membantu proses pembangunan kehidupan keluarga dengan mulus dan sejuk.

Terjalinnya komunikasi dari, oleh, dan untuk masyarakat akan menciptakan interaksi sosial yang positif. Interaksi ini didasarkan atas kesamaan kebutuhan, kekeluargaan, dan kegotongroyongan. Permasalahan yang mereka hadapi dapat dibicarakan bersama, saling mengingatkan, dan saling membantu sehingga terbentuk kembali kearifan lokal dan tatanan sosial yang merupakan warisan leluhur mereka. Kondisi inilah yang dapat dicapai melalui wahana Posdaya, termasuk modal sosial dalam mendukung penuntasan wajib belajar pendidikan dasar 9 tahun.

\section{Kegiatan Lanjutan Posdaya}

Aktivitas masyarakat dalam wahana Posdaya tidak hanya sebagai forum komunikasi tetapi dapat dikembangkan menjadi berbagai kegiatan yang bermanfaat bagi mereka. Aktivitas ini didasarkan pada kebutuhan dan potensi mereka serta melibatkan partisipasi yang tinggi. Menurut Suyono dan Haryanto (2008) kegiatan Posdaya dapat dikembangkan menjadi kelompok-kelompok Bina Keluarga Balita, Bina Keluarga Remaja, Bina Keluarga Dewasa, dan Bina Keluarga Lansia, Bina Keluarga Cacat, Bina Keluarga Ekonomi atau kelompok keluarga yang sedang membangun ekonomi, dan program pemberdayaan lainnya.

\section{Bina Keluarga Balita}

Salah satu bentuk kegiatan Posdaya adalah membina keluarga-keluarga yang memiliki anak di bawah lima tahun. Semua masyarakat dan pemerintah perlu memelihara kesehatan, mengembangkan kemandirian anak, merangsang tumbuh kembang yang optimal, serta deteksi dini kelainan atau kecacatan. Selain itu, dapat dikembangkan Pendidikan Anak Usia Dini (PAUD). Kelompok ini tidak hanya membina anak-anaknya melainkan juga para orang tua mereka dibina dalam hal menjaga kesehatan, merawat anak, dan sebagainya. Kelompok ini juga bisa melatih keterampilan atau kewirausahaan tertentu yang sesuai dengan potensi mereka. Jika memungkinkan para orang tua sambil menunggu anaknya dapat magang atau belajar di usaha-usaha produktif yang ada di sekitarnya.

Dalam kelompok ini peran pengurus atau yang dituakan dalam Posdaya sangat penting. Di sisi lain peran Depdiknas, Depkes, BKKBN, dan Pemda, serta masyarakat lainnya dapat menjadi fasilitator dalam mendorong aktivitas mereka. Pada akhirnya tahapan bina keluarga balita ini diharapkan mampu menyiapkan anak-anak yang sehat jasmani dan rohani, serta orang tua memiliki kemampuan dalam merawat dan mendidik anak bahkan memiliki keterampilan untuk meningkatkan ekonomi keluarga mereka, sehingga anak memiliki kesiapan untuk sekolah dan orang tuanya juga siap mendukung penuntasan wajib belajar 9 tahun. 


\section{Bina Keluarga Remaja}

Kelompok ini ditujukan untuk memberikan penyadaran kepada keluarga yang mempunyai anak remaja. Orang tua dengan anak remaja diharapkan memahami persoalan remaja, dan mendukung keberlangsungan sekolah mereka untuk menjadi anak yang dewasa dan mandiri. Melalui forum ini masalah-masalah tersebut dapat dibicarakan dan dicari solusi yang tepat. Begitu pula kendala-kendala yang dihadapi anak-anak mereka dalam belajar dapat dicari solusinya sehingga angka putus sekolah bisa dicegah. Pada kalangan remaja ini juga dikembangkan aktivitas yang positif, misalnya kegiatan keagamaan, olahraga, termasuk berlatih usaha atau magang pada ekonomi produktif, sehingga bisa membantu ekonomi keluarganya tanpa harus meninggalkan tugas utamanya bersekolah.

\section{Bina Keluarga Dewasa}

Kelompok ini ditujukan meningkatkan lebih lanjut upaya penyadaran keluarga yang mempunyai anak dewasa, agar anaknya terus diarahkan menjadi SDM yang handal, bermoral baik dan terus membina kualitasnya. Di sini anak-anak mereka sudah meyelesaikan pendidikan dasar 9 tahun bahkan mungkin sudah lulus tingkat SLTA. Selanjutnya mereka dibimbing dan diarahkan untuk mampu bekerja baik sebagai pekerja ataupun berwiraswasta. Mereka juga perlu disiapkan untuk berumahtangga yang berkualitas. Semua persoalan ini menjadi fokus pembicaraan dan diskusi dalam forum Posdaya. Dengan sharing pengalaman antarmereka akan menghasilkan solusi yang tepat.

\section{Bina Keluarga Lansia}

Kelompok ini ditujukan bagi keluarga yang memiliki anggota di atas usia 60 tahun. Di sini seluruh anggota keluarga dan masyarakat lainnya diarahkan untuk bisa memberikan suasana yang tenteram dan bahagia bagi para lansia. Para lansia diupayakan untuk aktif sehingga memiliki jiwa raga yang sehat dan tetap produktif. Sebaliknya lansia yang tidak mampu secara fisik dapat memperoleh kesempatan untuk mendapatkan tempat yang terhormat dalam lingkungan keluarga dan masyarakatnya.

\section{Bina Keluarga Cacat}

Keluarga cacat merupakan keluarga yang tidak hanya mempunyai keterbatasan karena menyandang cacat fisik melainkan juga keluarga yang memerlukan bantuan fasilitasi dalam mengembangkan kemampuannya. Melalui Posdaya, permasalahan dan kendala mereka dapat dibicarakan serta dicarikan solusi yang tepat sesuai dengan kemampuan mereka. Keluarga yang relatif sudah mampu memiliki kewajiban untuk membantu yang kurang mampu. Begitu pula dalam hal memperoleh kesempatan pendidikan, anak-anak cacat memiliki hak dan kesempatan yang sama untuk bisa menempuh pendidikan minimal setara SMP seperti anak-anak lainnya. Ini merupakan tanggung jawab bersama antara orang tua, pemerintah, dan juga masyarakat.

\section{Bina Keluarga Ekonomi}

Keluarga dari berbagai kelompok umur bisa bergabung bersama untuk mengembangkan kewirausahaan. Kebersamaan ini merupakan kombinasi antara keluarga kurang mampu dan keluarga yang lebih mampu. Di antara mereka memiliki kelebihan dan kelemahan masing-masing yang dapat disinergikan untuk membangun usaha bersama yang produktif dan menguntungkan. Bentuknya disesuaikan dengan potensi dan peluang yang ada. Usaha bersama dapat dikembangkan dengan cara koperasi atau dengan mengembangkan kebersamaan dalam usaha ekonomi produktif. Usaha ini dikembangkan atas dasar kebersamaan, saling membutuhkan, dan menguntungkan bersama pula. Usaha bersama ini juga lebih baik apabila mempekerjakan dari keluarga-keluarga miskin. Dengan demikian, roda ekonomi dalam masyarakat makin berputar, sehingga mereka termasuk yang miskin akan mendapatkan penghasilan untuk keluarganya. Akhirnya anak-anak mereka yang masih usia SMP tidak lagi diajak untuk bekerja mencari nafkah, tetapi mereka semua sekolah hingga tuntas wajib belajar 9 tahun, bahkan bisa melanjutkan ke jenjang yang lebih tinggi.

\section{Program Pemberdayaan lainnya}

Selama ini pemerintah memiliki banyak program yang terkait dengan pemberdayaan ekonomi, misalnya Program Nasional Pemberdayaan 
Masyarakat Mandiri (PNPM Mandiri) yang dikoordinasikan oleh Menteri Koordinator Kesejahteraan Rakyat (Menkokesra). Program ini dibagi menjadi dua jalur yaitu pemberdayaan untuk masyarakat perkotaan yang dikoor-dinasikan oleh Menteri Pekerjaan Umum dan program untuk masyarakat pedesaan yang dikoordinasikan oleh Menteri Dalam Negeri. Di samping itu ada beberapa program lain yang saling berkaitan yaitu program Keluarga Harapan yang dikoordinasikan oleh Menteri Sosial, Program Asuransi Kesehatan yang dikoordinasikan oleh Menteri Kesehatan, Program Beras untuk Keluarga Miskin atau Raskin yang dikoordinasi dan dilaksanakan oleh Menteri Sosial dan Bulog, Program untuk Desa Tertinggal dikoordinasikan oleh Menteri Pembangunan Daerah Tertinggal, Program Perkasa atau Koperasi untuk kaum perempuan yang dikoordinasikan oleh Menteri Koperasi dan UKM, Program KB untuk keluarga miskin yang dikoordinasikan oleh BKKBN dan masih banyak lagi.

Berbagai program ini menggunakan pendekatan pemberdayaan masyarakat walaupun dalam praktiknya tidak semulus yang diharapkan. Namun, jika program-program pemerintah tersebut diarahkan pelaksanaannya melalui Posdaya terutama bagi keluarga yang masih belum tuntas menamatkan pendidikan setara SMP maka penuntasan wajib belajar 9 tahun pada kelompok masyarakat hard rock ini dapat segera tuntas. Solusinya adalah kesadaran dan koordinasi antardepartemen, lembaga pemerintah, swasta, dan masyarakat. Akhirnya, Indek Pembangunan Manusia (Human Development Indeks) negara kita akan meningkat. Begitu pun sasaran dan tujuan MDGs segera tercapai dan yang lebih penting lagi kesejahteraan keluarga Indonesia meningkat.

\section{Simpulan dan Saran}

\section{Simpulan}

Penuntasan wajib belajar pendidikan dasar 9 tahun terutama pada kelompok masyarakat miskin, terpencil, atau suku terasing (hard rock) tidak cukup didekati dari aspek layanan pendidikan akan tetapi perlu dilakukan pemberdayaan terhadap keluarga sebagai satu unit kesatuan terkecil dari masyarakat. Untuk itu Posdaya dapat digunakan sebagai wadah untuk pencapaian wajar 9 tahun melalui pemberdayaan keluarga.

Posdaya merupakan forum silaturahmi, komunikasi, advokasi dan wadah kegiatan penguatan fungsi-fungsi keluarga secara terpadu. Fungsi keluarga tersebut adalah fungsi Ketuhanan Yang Maha Esa, fungsi budaya, fungsi cinta kasih, fungsi perlindungan, fungsi reproduksi dan kesehatan, fungsi pendidikan, fungsi ekonomi atau wirausaha dan fungsi lingkungan. Semua fungsi tersebut dapat disederhanakan menjadi 3 aspek, yaitu aspek pendidikan, kesehatan, dan kewirausahaan yang merupakan pondasi mewujudkan keluarga sejahtera.

Pengembangan Posdaya tidak harus membuat lembaga atau organisasi baru dalam masyarakat, tetapi dapat mengoptimalkan yang telah ada misalnya Posyandu, Masjid, Gereja, Pura, Sekolah, Pesantren, Pengajian Ibu-Ibu, Kelompok Tani, Kelompok Nelayan, Kelompok Adat, dan lainnya dengan meningkatkan aktivitas pemberdayaan yang sesuai kebutuhan, permasalahan, dan potensi masyarakat setempat.

Sebagai forum komunikasi informal dari, oleh, dan untuk masyarakat, posdaya dapat menjadi wahana untuk berdiskusi atau bertukar pengalaman dalam memecahkan permasalahan yang mereka hadapi sehari-hari. Oleh karena itu, kendala-kendala yang dapat menghalangi penuntasan wajar 9 tahun bisa diantisipasi dan dipecahkan bersama oleh anak, orang tua, dan masyarat sekitarnya sesuai dengan kebutuhan, permasalahan, dan potensi/peran masing-masing.

Melalui forum komunikasi dan silaturahmi yang didasari oleh kebersamaan dan kesadaran, Posdaya akan mampu membangun kembali kearifan lokal dan tatanan sosial atau modal sosial seperti sifat kegotongroyongan, kekeluargaan dan tolong menolong di antara anggota masyarakat. Modal sosial ini sangat penting dimiliki masyarakat dalam menuntaskan wajib belajar 9 tahun.

Posdaya tidak hanya menuntaskan masalah pendidikan, akan tetapi juga masalah lain yang ada di masyarakat seperti kesehatan dan kewirausahaan, sehingga pengembangan posdaya yang mampu memberikan partisipasi seluas-luasnya kepada masyarakat, berorientasi pada kebutuhan sebagian besar masyarakat serta 
menggunakan pendekatan holistik, akan mampu meningkatkan keluarga Indonesia lebih sejahtera.

\section{Saran}

Penuntasan wajib belajar pendidikan dasar 9 tahun pada kelompok masyarakat hard rock memerlukan kerja sama lintas departemen di bawah koordinasi Menkokesra. Sektor pendidikan, kesehatan, dan kewirausahaan perlu diarahkan secara terpadu memfokuskan perhatian kepada kelompok masyarakat yang memiliki anak yang belum tuntas menamatkan pendidikan dasar 9 tahun. Dengan keterpaduan ini tidak hanya aspek pendidikan dasar yang bisa dituntaskan, namun aspek kesehatan dan kesejahteran keluarga juga akan mampu terwujud.

Penyadaran terhadap orang tua yang memiliki anak yang belum menamatkan pendidikan dasar
9 tahun perlu terus dilakukan, di antaranya dengan memberdayakan mereka melalui suatu wadah yaitu Posdaya. Oleh karena itu, semua pihak terkait perlu mendukung keberhasilan Posdaya sebagai salah satu model pem-berdayaan keluarga terutama dalam aspek pendidikan, kesehatan, kewirausahan, dan sebagainya.

Program pemberdayaan yang dimiliki pemerintah seperti PNPM mandiri, Program Perkasa, Program Keluarga Harapan, dan program lainnya hendaknya difokuskan bagi kelompok masyarakat yang memiliki anak-anak usia SMP, lebih diutamakan lagi kepada kelompok masyarakat hard rock yang anak-anaknya belum mencapai pendidikan setingkat SMP. Dengan cara ini program pemerintah akan dilaksanakan secara terpadu, sehingga tidak hanya aspek pendidikan yang meningkat tetapi kesejahteraan masyarakat akan meningkat pula.

\section{Pustakan Acuan}

Anwas, Oos M. 2009. Kampanye Pembangunan via Televisi. Jakarta: Majalah Gemari edisi 99/X April 2009.

Asngari, Pang S. 2007. Bahan Kuliah: Prinsip-prinsip Penyuluhan Pembangunan. Ilmu Penyuluhan Pembangunan Pascasarjana IPB Bogor.

Balitbang Depdiknas. 2007. Educational Statistic In Brief 2006/2007. Jakata: Pusat Statistik Pendidikan, Balitbang Depdiknas.

Damandiri. 2009. Evaluasi Program Yayasan Damandiri dan Perkembangannya sampai dengan April 2009. Jakarta: Yayasan Damandiri.

Fukuyama, Franciscus. 2000. The Great Distruption; Human Nature and the Reconstitution of Social Order. London: Profile Books.

Kincaid, D. Lawrence dan Schramm, Wilbur. 1987. Asas-Asas Komunikasi Antar Manusia. Edisi Indonesia. Jakarta: LP3ES

Rogers, Everett M. 1995. Diffusion of Innovations. Fourh Edition. New York:The Free Press.

Sendjaja, Sasa Djuarsa dan Illya Sumawinata. 1994. Teori Komunikasi; Materi Pokok Modul Universitas Terbuka, Jakarta: UT.

Slamet, Margono. 2007. Bahan Kuliah Manajemen Kelompok dan Organisasi, Ilmu Penyuluhan Pembangunan Pascasarjana IPB Bogor.

Sumardjo, 2008. Penyuluhan Pembangunan Pilar Pendukung Kemajuan dan Kemandirian Masyarakat. Artikel dalam buku: Memberdayakan Manusia Pembangunan yang Bermartabat. Bogor: Pustaka Bangsa Press.

Susanto, Djoko. 2007. Komunikasi Pembangunan dalam Perspektif PS-PPN. Program Studi Ilmu Penyuluhan Pembangunan, Pascasarjana IPB Bogor.

Suyono, Haryono dan Rohadi Haryanto. 2009. Pedoman Pembentukan dan Pengembangan Pos Pemberdayaan Keluarga; Posdaya. Jakarta: Balai Pustaka.

Suyono, Haryono. 2003. Memotong Rantai Kemiskinan. Jakarta: Yayasan Dana Sejahtera Mandiri. 